Article

\title{
Provenance Variation in Pinus palustris Foliar $\delta^{13} \mathrm{C}$
}

\author{
Lisa Samuelson ${ }^{1, *}$, Kurt Johnsen ${ }^{2}$, Tom Stokes ${ }^{1}$, Peter Anderson ${ }^{3}$ and C. Dana Nelson 4 (i) \\ School of Forestry and Wildlife Sciences, Auburn University, Auburn, AL 36849, USA; stoketa@auburn.edu \\ 2 USDA Forest Service, Southern Research Station, 1577 Brevard Road, Asheville, NC 28806, USA; \\ kjohnsen@fs.fed.us \\ 3 USDA Forest Service, Southern Research Station, 3041 East Cornwallis Road, \\ Research Triangle Park, NC 27709, USA; phanderson@fs.fed.us \\ 4 USDA Forest Service, Southern Research Station, 730 Rose Street, Lexington, KY 40546, USA; \\ dananelson@fs.fed.us \\ * Correspondence: samuelj@auburn.edu; Tel.: +1-334-844-1040
}

Received: 5 July 2018; Accepted: 31 July 2018; Published: 1 August 2018

check for updates

\begin{abstract}
Longleaf pine forests are currently being restored in the southern U.S. To aid in the deployment of longleaf pine under current and future climate conditions, we tested the hypothesis that genetic variability in foliar carbon isotope composition $\left(\delta^{13} \mathrm{C}\right)$ exists in this species. Foliar $\delta^{13} \mathrm{C}$, height and diameter were measured at ages of 5 and 6 years, and needle length, specific leaf weight (SLW) and foliar $\mathrm{N}$ concentration were measured at an age of 6 years in 16 longleaf pine families representing a large portion of the species' range. Families were grown in common garden tests in North Carolina and Mississippi and grouped for analysis into six provenances based on climate, soils, and discontinuities in the species' range. No genetic by environment interactions were observed. Greater foliar $\delta^{13} \mathrm{C}$ was observed in trees from the provenance consisting of the Piedmont and Montane Uplands than from the provenances representing the western and eastern Gulf Coastal Plains. Foliar $\delta^{13} \mathrm{C}$ was not significantly correlated to height at age 6 , suggesting that it may be possible to select for improved foliar $\delta^{13} \mathrm{C}$ without sacrificing growth. These results represent a first step in identifying potential genetic variation in leaf water use efficiency and drought tolerance of longleaf pine.
\end{abstract}

Keywords: climate change; common gardens; longleaf pine; water use efficiency

\section{Introduction}

The severe reduction in the extant of longleaf pine (Pinus palustris Mill.) forests in the southern U.S. has resulted in increased interest in restoring this ecosystem throughout its natural range for a variety of forest products and ecosystems services, including potential mitigation of climate change impacts on southern forests [1-3]. Longleaf pine has the ability to grow on sites with low water holding capacity and low soil nutrition relative to the other pines in the southern U.S., and is more resistant to wind and pest damage [4]. Proper deployment of seed source to site would assist in longleaf pine reforestation efforts, as well as assist in planting seedlings better adapted to future climate conditions [5]. However, in comparison to some other southern U.S. pines, studies of geographic variation in longleaf pine are rare and have generally not been extensive and intensive in sampling [6,7]. Wells \& Wakeley [8] demonstrated that significant geographic variation in survival, initiation of height growth from the grass stage, growth characteristics, and disease resistance exists in longleaf pine. Considering the resurgence of interest in artificially regenerating longleaf pine by federal and state agencies and private landowners, there is a need for a better understanding of potential genetic adaptation to climate in an important conifer that is being restored throughout the southern U.S. 
Although local seed sources are often assumed to be better adapted to local conditions, local sources may not be suitable under future climate conditions [9].

The isotopic ratio of ${ }^{13} \mathrm{C}$ to ${ }^{12} \mathrm{C}$ in plant tissue relative to a geologic standard is expressed as foliar carbon isotopic composition $\left(\delta^{13} \mathrm{C}\right)$. The $\delta^{13} \mathrm{C}$ in leaf tissues of $\mathrm{C}_{3}$ plants provides a long-term index of the ratio of internal to ambient partial pressure of $\mathrm{CO}_{2}$ within the leaf, or $C_{i} / C_{a}$, and $C_{i} / C_{a}$ is determined by the time-integrated ratio of net photosynthesis to stomatal conductance, or intrinsic leaf water use efficiency (WUE), during leaf formation [10,11]. Genetic variation in foliar $\delta^{13} \mathrm{C}$ has been reported for a variety of conifers including Pinus pinaster Ait. [12], Pseudotsuga menziesii (Mirb.) Franco [13], Pinus radiata D. Don [14], Pinus ponderosa C. Lawson [15], and Picea mariana Mill. [16]. In some cases, genetic variation in foliar $\delta^{13} \mathrm{C}$ was related to improved drought tolerance [17]. Increased WUE during drought may limit soil and plant water depletion, maintain cell and tissue turgor, and prolong survival [17]. Gonzalez-Benecke \& Martin [18] reported genotype differences in foliar $\delta^{13} \mathrm{C}$ and stomatal control of water loss under water-limited conditions in loblolly pine (Pinus taeda L.), another important southern conifer, and suggested that variation in foliar $\delta^{13} \mathrm{C}$ among genotypes may improve genetic deployment programs for loblolly pine under future climate change scenarios. Likewise, based on negative correlations between 3rd-year height and foliar stable carbon isotope discrimination at the parental, full-sib family and clonal levels, Baltunis et al. [19] also suggested that foliar $\delta^{13} \mathrm{C}$ could be used as a selection trait to improve WUE and guide deployment decisions in loblolly pine. Common garden experiments with tree seedlings have found geographic variation in phenotypic traits corresponding to gradients in climate [20], and such provenance tests have been used to predict growth responses of trees to climate change [21,22]. For example, Farjat et al. [23] used height data from range-wide loblolly pine provenance tests to map optimal seed source deployment under different climatic change scenarios.

Given longleaf pine's wide geographic and site amplitude [24], we hypothesized that genetic variation in foliar $\delta^{13} \mathrm{C}$ also exists in this species. Furthermore, based on work with loblolly pine that demonstrated significant genotype by site interactions for foliar stable carbon isotope discrimination and height [19], we hypothesized that the genetic by environment interaction would be significant for growth and foliar $\delta^{13} \mathrm{C}$. We tested this by measuring these traits over 2 years at two common gardens that represent variation in temperature and precipitation. Because longleaf pine is found on dry sites throughout its range and no information on genetic variation in WUE exists for longleaf pine, we had no a priori expectation of provenance ranking in foliar $\delta^{13} \mathrm{C}$. Foliar $\delta^{13} \mathrm{C}$ was positively related to genotype height in loblolly pine [25]. We, therefore, expected that foliar $\delta^{13} \mathrm{C}$ in longleaf pine would be positively related to tree height. Because needle length can also be positively related to tree growth [26], we tested the hypothesis that provenances with greater growth would also have greater needle length. As variation in specific leaf weight (SLW) may influence mesophyll conductance and variation in foliar $N$ may influence net photosynthetic rates, both of which may affect $C_{i} / C_{a}$ [27], provenance variation in these variables was also measured.

\section{Materials and Methods}

Eight provenance tests were planted across the range of longleaf pine. Two longleaf pine provenance tests were selected for sampling: one in North Carolina (NC) and one in Mississippi (MS). These two tests were selected to provide variation in climate and test genetic by environment interactions. Up to 151 seed collections (mostly open-pollinated families from seed orchard trees) originating from southern Alabama, northern Alabama, Georgia, Florida, Louisiana, Mississippi, North Carolina, Texas, and Virginia were planted at all provenance tests. Seeds were collected from seed orchards across the region (where progeny had not been tested or only minimally tested) as well as some bulk (multiple tree) collections from natural stands. Seeds were sown in $164 \mathrm{~cm}^{3}$ containers at North Carolina State University Horticulture Field Laboratory mist house in Raleigh, NC from 25 May-7 June 2010 and then moved outdoors to a seedling pad in June/July 2010. At each provenance test location, seedlings were planted on a $3.6 \mathrm{~m}$ by $1.8 \mathrm{~m}$ spacing. 
In order to examine range-wide patterns, 16 different families (Table 1) selected from across the species' range were selected for study and grouped into six provenances (Figure 1) based on climate, soils, and discontinuity of the range (e.g., west/ east of the Mississippi River and north/south of the Piedmont physiographic province) [28].

Table 1. Provenance physiographic province, origin and number of longleaf pine families studied per provenance, and mean minimum temperature at the family origin.

\begin{tabular}{|c|c|c|c|c|c|}
\hline Provenance & $\begin{array}{c}\text { Provenance } \\
\text { Physiographic } \\
\text { Province }^{1}\end{array}$ & Family Origin & $\begin{array}{c}\text { Latitude, } \\
\text { Longitude } \\
\text { (Degrees) }\end{array}$ & $\begin{array}{l}\text { Number of } \\
\text { Families }\end{array}$ & $\begin{array}{l}\text { Mean Minimum } \\
\text { Temperature }{ }^{2}\left({ }^{\circ} \mathrm{C}\right)\end{array}$ \\
\hline \multirow[t]{2}{*}{1} & \multirow[t]{2}{*}{ WGCP } & Sabine Co., TX & $\begin{array}{c}31.3432 \\
-93.8518\end{array}$ & 1 & 12.9 \\
\hline & & Vernon Parish, LA & $\begin{array}{r}31.1083 \\
-93.1842\end{array}$ & 2 & 12.1 \\
\hline \multirow[t]{2}{*}{2} & \multirow[t]{2}{*}{ EGCP } & Perry Co., MS & $\begin{array}{l}31.1720 \\
-88.9923\end{array}$ & 1 & 11.6 \\
\hline & & Escambia Co., AL & $\begin{array}{c}31.1261 \\
-87.1616\end{array}$ & 1 & 11.7 \\
\hline \multirow[t]{2}{*}{3} & \multirow[t]{2}{*}{ SCP } & Baker Co., FL & $\begin{array}{r}30.3311 \\
-82.2846\end{array}$ & 1 & 14.2 \\
\hline & & Wakulla Co., FL & $\begin{array}{c}30.1478 \\
-84.3756\end{array}$ & 2 & 13.2 \\
\hline \multirow[t]{3}{*}{4} & \multirow[t]{3}{*}{$\mathrm{P}, \mathrm{MU}$} & Chilton Co., AL & $\begin{array}{c}32.8479 \\
-86.7188\end{array}$ & 1 & 10.3 \\
\hline & & Bibb Co., AL & $\begin{array}{r}32.9986 \\
-87.1264\end{array}$ & 2 & 9.4 \\
\hline & & Cleburne Co., AL & $\begin{array}{c}33.6746 \\
-85.5188\end{array}$ & 1 & 10.0 \\
\hline 5 & EGCP, ACP & Burke Co., GA & $\begin{array}{c}33.0612 \\
-82.0080\end{array}$ & 2 & 11.2 \\
\hline \multirow[t]{2}{*}{6} & \multirow[t]{2}{*}{$\mathrm{ACP}, \mathrm{FS}$} & Harnett Co., NC & $\begin{array}{c}35.3686 \\
-78.8693\end{array}$ & 1 & 11.1 \\
\hline & & Bladen Co., NC & $\begin{array}{r}34.6143 \\
-78.5632\end{array}$ & 1 & 9.9 \\
\hline
\end{tabular}

1 WGCP, Western Gulf Coastal Plain; EGCP, Eastern Gulf Coastal Plain; SCP, Southern Coastal Plain; P, Piedmont; MU, Montane Uplands; ACP, Atlantic Coastal Plain; FS, Fall-line Sandhills [29]. ${ }^{2}$ 30-year (1980-2010) means [30].

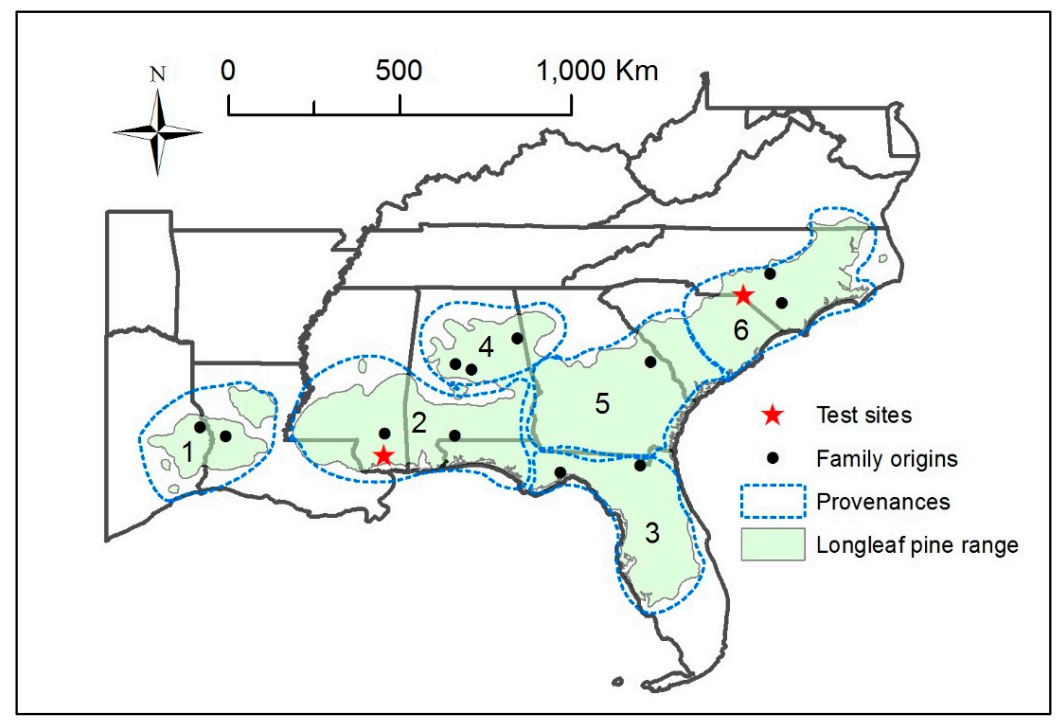

Figure 1. Location of the six provenances and two provenance test locations, and the origin of longleaf pine families within the natural range of longleaf pine. 


\subsection{MS and NC Provenance Tests}

At both provenance test locations, the experimental design was a randomized complete block with 10 replicates and 2-tree plots. Sixteen families common to the two test sites were sampled from four blocks at each site (Table 1, Figure 1). A family consisted of a seed from one open-pollinated mother tree and in some cases different mother trees were from the same location (Table 1). The numbers of families and blocks were based on survival within and across sites. The selection of the four blocks was based on whether the block contained live individuals of all of the 16 families. All sample trees were out of the grass stage at the time of sampling. Longleaf pine seedlings have a juvenile grass stage with delayed height growth that may last for several years.

The MS test is located in the Gulf Coastal Plain on the USDA Forest Service Harrison Experimental Forest, near Saucier MS (30.609988, -89.055431). Thirty-year (1984-2013) average annual precipitation for Harrison Experimental Forest is $1700 \mathrm{~mm}$ [31]. Soils are well-drained, fine sandy loams in the Poarch series and the Saucier-Susqhehanna complex. The site was clear-cut a few years prior to planting and bush-hogged immediately prior to planting. Seedlings were hand planted on 15-16 December 2010. Herbicide was sprayed over the top of the trees in June 2013. All test seedlings were protected from herbicide contact. The planting was bush-hogged between rows two times a year from 2011 through 2013. The site was burned on 2 April 2014. Weather data collected during the 2-year study period were also from the Harrison Experimental Forest and the Palmer Drought Severity Index (PDSI) data were from MS PDSI Climate Division 10 [31,32].

The NC test is located in Scotland County, NC $(34.822999,-79.567006)$ on North Carolina Forest Service land. Soil at the site is a Norfolk loamy sand. Thirty-year (1984-2013) average annual precipitation for Laurinburg, NC (12 km from the site) is $1149 \mathrm{~mm}$ [33]. Prior to planting, the site was a fallow field. Seedlings were hand-planted on 11 March 2011. The site was mowed periodically. Weather data collected during the 2-year study period were also from Laurinburg, NC, and PDSI data were from NC PDSI Climate Division 5 [33,34].

\subsection{Measurements}

In 2014, four fascicles from the first flush were collected from the top one third of the canopy from each cardinal direction of one tree of a given family in the 2-tree plot (in total, 64 trees per test site). Since branching was not observed across all sample trees, needles were collected from the main stem. Foliage was collected the week of 17 November at both sites. In 2015, fascicles were collected from up to four unshaded branches located a minimum of $1 \mathrm{~m}$ above the soil during the last week of November (MS) and the first week of December (NC). Needle lengths and SLW were measured on all collected needles. Needle lengths and diameters were measured and total needle area per fascicle determined following Samuelson et al. [35]. Foliage was oven-dried at $70^{\circ} \mathrm{C}$ to a constant weight and the ratio of dry weight to total area was used to calculate SLW. Dried needles were then pooled by tree and ground to a fine homogeneous powder using a ball mill grinder (Spex 8000, SPEX SamplePrep LCC, Metuchme, NJ, USA). The ${ }^{13} \mathrm{C}:{ }^{12} \mathrm{C}$ ratio was measured using a continuous flow mass spectrometer (Thermo Finnigan Plus XL, Thermo Fisher Scientific, Waltham, MA, USA) and foliar nitrogen (N) concentration was measured using a Carlo-Erba analyzer (NA 1500 Series I, Carlo Erba Instrumentation, Milan, Italy) at The Duke Environmental Stable Isotope Laboratory. Foliar $\mathrm{N}$ concentration was measured on foliage collected in 2015. Total height (to the tip of terminal bud) and DBH (at $1.37 \mathrm{~m}$ height) were measured each year on the sample trees at the time of foliage collection.

\subsection{Data Analyses}

The main and interaction effects of site, year of measurement (for foliar $\delta^{13} \mathrm{C}$, height and $\mathrm{DBH})$, provenance, and family within provenance were analyzed using repeated measures ANOVA (Proc Mixed, SAS Inc., Cary, NC, USA) and a cross-nested design with family nested within provenance and blocks nested within site. The effects of year were tested in the analyses to determine if the genetic 
by environment interaction was stable across years. The genetic by environment interaction was tested by the site by provenance interaction term. The covariance structure for each variable was selected based on the Akaike Information Criterion fit statistic. Where appropriate, block within site was considered a random factor. Effects were considered significant at $\alpha \leq 0.05$. When provenance was significant, means were separated using Tukey's paired comparison procedure. When an interaction was significant, the SLICE option of Proc Mixed was used for means separation. Based on patterns of residuals, no data transformations were necessary. Correlation between foliar $\delta^{13} \mathrm{C}$ and height at age 6 was examined by site using the Pearson product-moment correlation coefficient.

\section{Results}

\subsection{Climate}

Monthly maximum temperatures during the 2-year study were similar between sites, but minimum monthly temperatures were lower during winter and spring months at NC (Figure 2). In MS, annual precipitation was $1757 \mathrm{~mm}$ in 2014 and $2200 \mathrm{~mm}$ in 2015 compared to $1205 \mathrm{~mm}$ in 2014 and $1323 \mathrm{~mm}$ in 2015 at NC. Monthly precipitation during spring and summer months was generally higher in MS than in NC (Figure 2). The PDSI indicated mild drought conditions in late 2014 and early 2015 at MS and moderate to severe drought conditions in NC in the summer of 2015 (Figure 3).

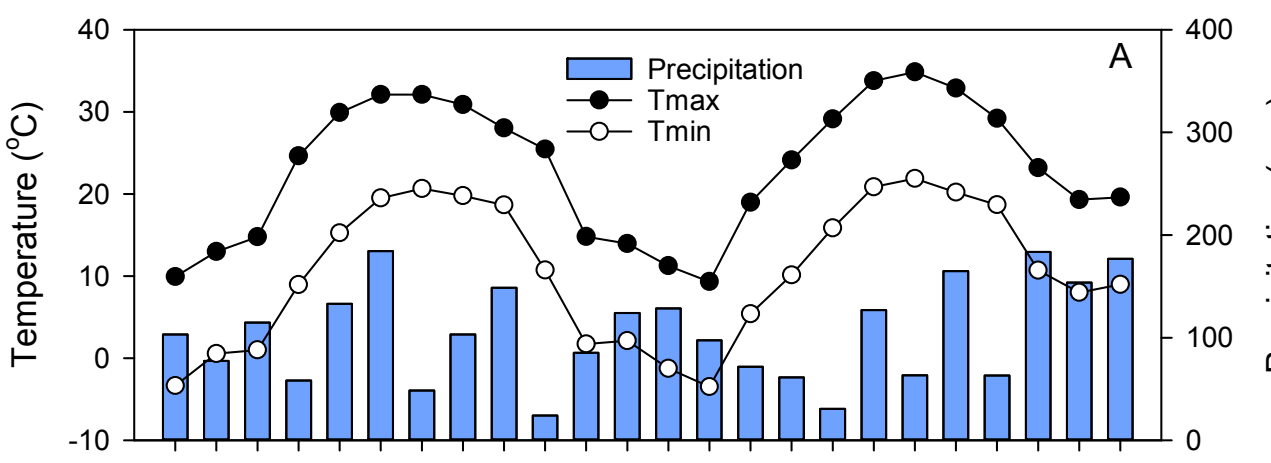

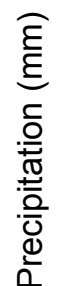

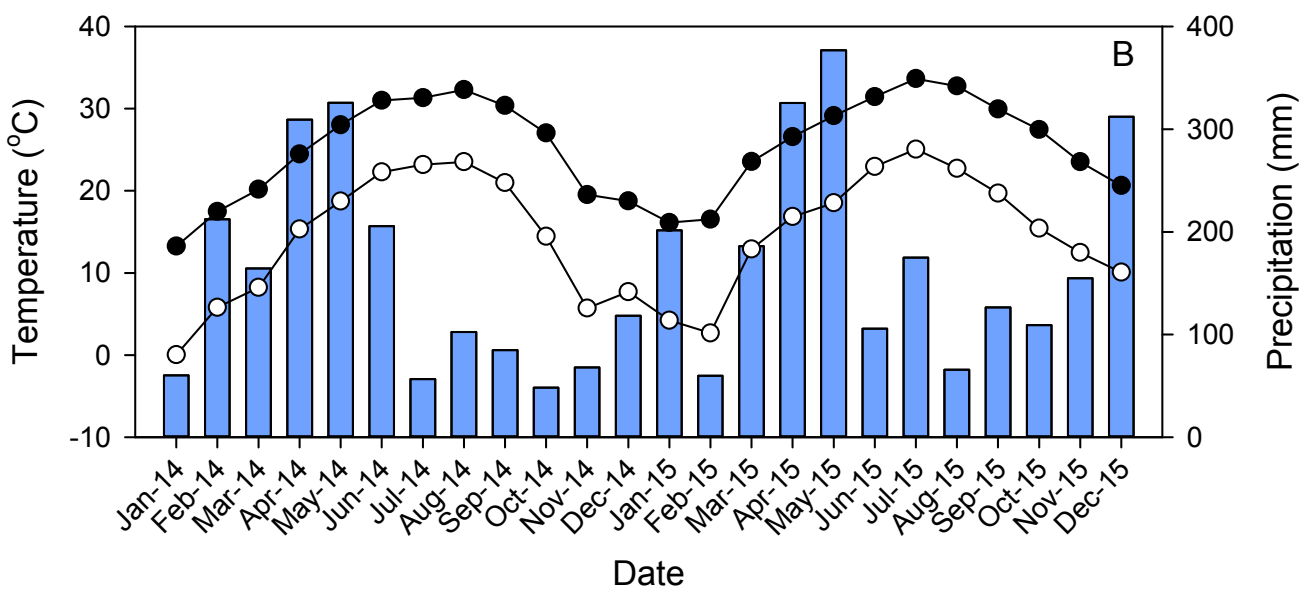

Figure 2. Average monthly minimum (Tmin) and maximum (Tmax) temperatures and total monthly precipitation at the North Carolina (A) and Mississippi (B) provenance test sites during the 2-year study. 

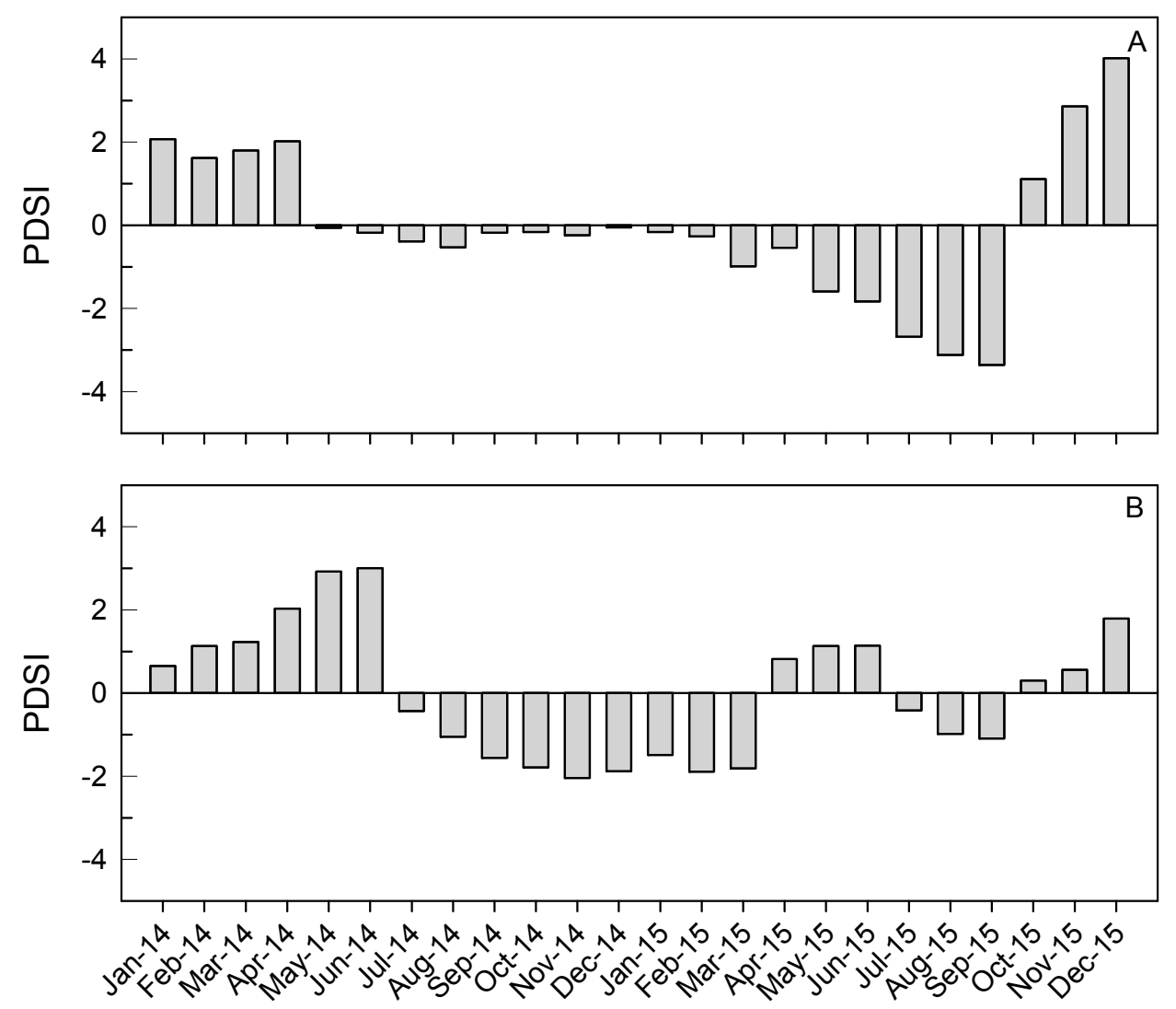

Date

Figure 3. The Palmer Drought Severity Index (PDSI) at the North Carolina (A) and Mississippi (B) provenance test sites during the 2-year study.

\subsection{Tree Growth}

No significant site by provenance or site by family within provenance interactions were observed for height or DBH (Table 2). Mean DBH and height were greater in $2015(4.9 \pm 0.1 \mathrm{~cm}$ and $2.7 \pm 0.1 \mathrm{~m}$, respectively) than in $2014(3.2 \pm 0.1 \mathrm{~cm}$ and $1.6 \pm 0.04 \mathrm{~m}$, respectively). Mean DBH did not vary significantly among provenances (Table 2, Figure 4 ) or families within provenance (Table 2). Significant interactions between site and year were observed for DBH and height (Table 2). Mean DBH was greater in NC $(3.6 \pm 0.1 \mathrm{~cm})$ than in MS $(2.7 \pm 0.2 \mathrm{~cm})$ in 2014 but similar between sites in 2015 (5.1 $\pm 0.1 \mathrm{~cm}$ versus $4.6 \pm 0.1 \mathrm{~cm}$ in NC and MS, respectively). Mean height was also greater in NC $(1.8 \pm 0.1 \mathrm{~m})$ than in MS $(1.4 \pm 0.1 \mathrm{~m})$ in 2014 but similar between sites in $2015(2.8 \pm 0.1 \mathrm{~m}$ versus $2.6 \pm 0.1 \mathrm{~m}$ in NC and MS, respectively). Significant variation in height among provenances and families within provenance was observed (Table 2). Average height was greater in trees from Provenance 1 than from Provenance 6 (Figure 4). The significant family within provenance effect indicated family variation in height in Provenance 6; height was greater in the Harnett County family $(2.3 \pm 0.2 \mathrm{~m})$ than in the Bladen County family $(1.4 \pm 0.2 \mathrm{~m})$. 
Table 2. Probability values for main and interactive effects of year (for repeatedly measured variables), provenance test site, provenance, and family nested within provenance on tree size and needle traits of longleaf pine.

\begin{tabular}{ccccccc}
\hline Source of Variation & Height & DBH & $\begin{array}{l}\text { Needle } \\
\text { Length }\end{array}$ & SLW & Foliar $\boldsymbol{\delta}^{\mathbf{1 3}} \mathbf{C}$ & Foliar N \\
\hline Year & $<0.001$ & $<0.001$ & & & $<0.001$ & \\
Site & 0.004 & $<0.001$ & 0.235 & 0.001 & $<0.001$ & 0.012 \\
Provenance & 0.022 & 0.107 & 0.028 & 0.014 & $<0.001$ & 0.502 \\
Family (Provenance) & $<0.001$ & 0.076 & 0.683 & 0.557 & 0.318 & 0.779 \\
Site $\times$ Provenance & 0.749 & 0.981 & 0.818 & 0.576 & 0.462 & 0.132 \\
Site $\times$ Family (Provenance) & 0.982 & 0.992 & 0.652 & 0.521 & 0.691 & 0.337 \\
Year $\times$ Site & 0.001 & 0.017 & & & 0.276 & 0.435 \\
Year $\times$ Family (Provenance) & 0.200 & 0.081 & & & 0.678 & \\
Year $\times$ Site $\times$ Provenance & 0.840 & 0.575 & & & 0.314 & \\
Year $\times$ Site $\times$ Family (Provenance) & 0.905 & 0.624 & & & &
\end{tabular}

DBH, diameter at breast height; SLW, specific leaf weight.
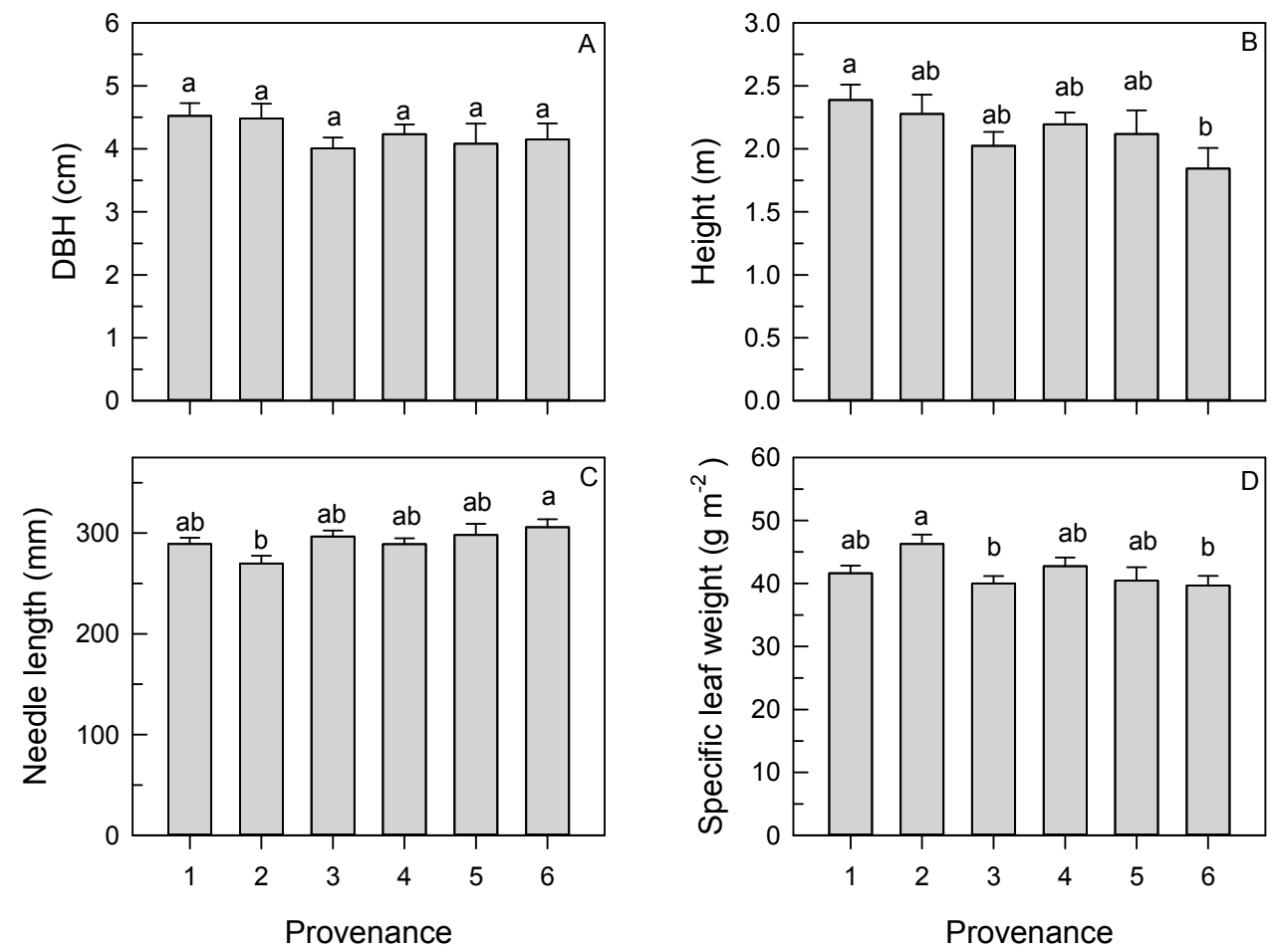

Figure 4. Mean (SE) diameter at breast height (DBH) (A), height (B), needle length (C), and specific leaf weight (D) of longleaf pine trees from different provenances. Different letters indicate significant differences among provenances. Means reflect data pooled across two provenance test sites and 2 years (where applicable).

\subsection{Needle Length and Specific Leaf Weight}

No significant site by provenance or site by family within provenance interactions were observed for needle length or SLW (Table 2). Needle length varied among provenances but not between sites (Table 2). Needle length was greater in trees from Provenance 6 than from Provenance 2 (Figure 4). No significant effect of family within provenance on needle length was observed (Table 2).

Specific leaf weight varied between sites (Table 2) with higher SLW in MS (44.1.2 $\pm 1.2 \mathrm{~g} \mathrm{~m}^{2}$ ) than in NC $\left(39.5 \pm 0.8 \mathrm{~g} \mathrm{~m}^{2}\right)$. Specific leaf weight varied with provenance but not family within provenance (Table 2). Provenance 2 had higher SLW than Provenances 3 and 6 (Figure 4). 


\subsection{Foliar $\delta^{13} \mathrm{C}$ and $\mathrm{N}$ Concentration}

No significant interaction effects between site and provenance, and between site and family within provenance were observed for foliar $\delta^{13} \mathrm{C}$ (Table 2). In addition, despite variations in climate between sites and years, no significant three-way interactions between year, site and provenance were detected for foliar $\delta^{13} \mathrm{C}$. Main effects of provenance, site and year on foliar $\delta^{13} \mathrm{C}$ were observed. Trees from Provenance 4 had higher average foliar $\delta^{13} \mathrm{C}(-29.45 \% 0 \pm 0.09 \%$ ) than trees from Provenances 1 $(-30.08 \% 0 \pm 0.10 \%)$ and $2(-30.06 \% 0 \pm 0.12 \%)$ (Figure 5). Higher foliar $\delta^{13} \mathrm{C}$ was observed in $2015(-29.20 \% 0 \pm 0.06 \%$ o $)$ than in $2014\left(-30.48 \% \pm 0.06 \%\right.$, and foliar $\delta^{13} \mathrm{C}$ was higher in NC $(-29.28 \% \pm \pm 0.07 \%$ o $)$ than in MS $\left(-30.40 \%\right.$ o $\pm 0.07 \%$ ). Foliar $\delta^{13} \mathrm{C}$ and height were not significantly correlated at either provenance test, though a trend $(p=0.058)$ was detected in MS (Figure 6).
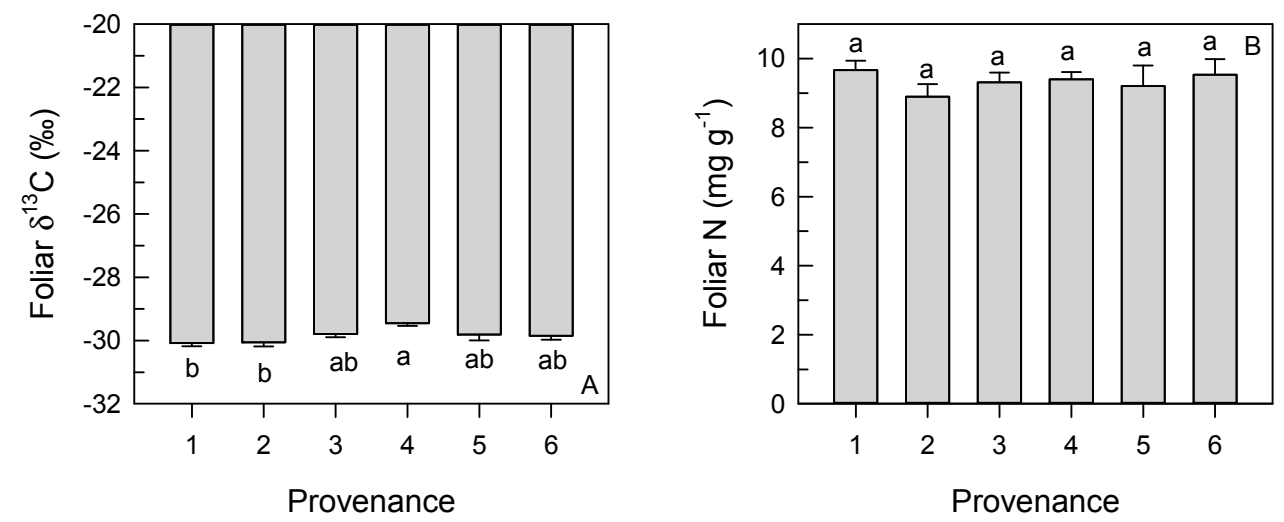

Figure 5. Mean (SE) foliar $\delta^{13} \mathrm{C}$ composition (A) and leaf nitrogen concentration (B) of longleaf pine trees from different provenances. Different letters indicate significant differences among provenances. Means reflect data pooled across two provenance test sites and 2 years (where applicable).
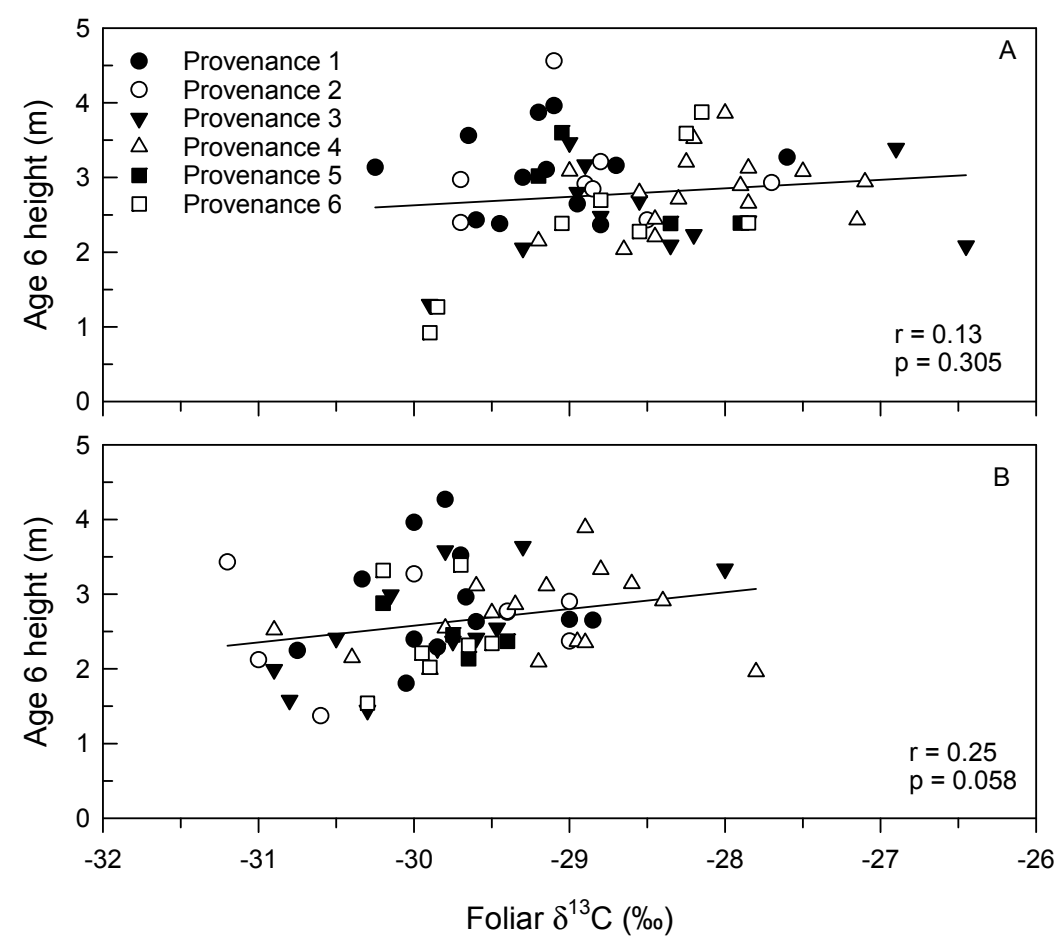

Figure 6. Correlation between height at age 6 and foliar $\delta^{13} \mathrm{C}$ composition of longleaf pine trees from different provenances at the North Carolina (A) and Mississippi (B) provenance test sites. 
Average foliar N concentration was higher in MS $\left(10.0 \pm 0.3 \mathrm{mg} \mathrm{g}^{-1}\right)$ than in NC $\left(8.7 \pm 0.3 \mathrm{mg} \mathrm{g}^{-1}\right)$ (Table 2). Foliar $\mathrm{N}$ concentration did not vary significantly with provenance (Figure 5 ) or family within provenance and no interactive effect of site and provenance or site and family within provenance on foliar $\mathrm{N}$ was observed (Table 2).

\section{Discussion}

Phenotypic variability in ecophysiological traits may reduce vulnerability to stresses associated with climate change [36]. For example, high variability in WUE and needle elongation across a large latitudinal gradient were related to range shifts associated with climate change in Pinus jeffreyi Grev. \& Balf. and Abies concolor (Gord. \& Glend.) Lindl. ex Hildebr. [36]. Phenotypic plasticity in SLW, foliar $\mathrm{N}$ concentration and foliar $\delta^{13} \mathrm{C}$ of longleaf pine was observed in this study. Higher SLW at MS was likely related to site differences in soil $\mathrm{N}$ availability and subsequent higher foliar $\mathrm{N}$ concentration at MS. Specific leaf weight has been shown to be positively related to foliar $\mathrm{N}$ concentration in longleaf pine [37] and Pinus pinaster trees [38], and to N fertilization in Pinus radiata [39]. The increase in SLW with improved fertility can be through an increase in needle density or thickness [38]. We speculate that higher foliar $\delta^{13} \mathrm{C}$ at NC was in response to greater water stress at that location, since SLW was lower at $\mathrm{NC}$ and genotypes with leaves that are thinner or less dense have shown decreases in WUE and foliar $\delta^{13} \mathrm{C}[40]$.

Provenance variation was significant for height, needle length, SLW and foliar $\delta^{13} \mathrm{C}$ but not for foliar N concentration or DBH. Greater height was observed in the provenance west of the Mississippi River than in the provenance encompassing the northern Atlantic Coastal Plain. Previous provenance studies of longleaf pine indicated that geographic sources from warmer climates grow faster than sources from colder climates, if sources are not transferred to very different climates [41]. Growth and survival of longleaf pine has been shown to exhibit a strong north-south component of variation related to mean annual minimum temperature [7]. However, provenance variation in height did strictly follow variation in mean minimum temperature of the family origin, as the mean minimum temperatures at the family origin were highest in Provenance 3 followed by Provenance 1 (Table 1). Height was the only variable with significant family within provenance variation. Height was less in the family from Bladen County, an inland area of North Carolina described as the Fall-line Sandhills [29], than in the more coastal family. Provenance variation in needle length and SLW was observed but neither mirrored provenance variation in height or foliar $\delta^{13} \mathrm{C}$. In contrast, Cregg [42] observed shorter needles and less surface area per needle in ponderosa pine seedlings from drought-tolerant sources. On the other hand, Aspinwall et al. [25] observed significant genetic variation in WUE but no variation in specific leaf area among loblolly pine genotypes.

Significant provenance variation in foliar $\delta^{13} \mathrm{C}$ suggests greater WUE in trees from Provenance 4, which consists of the Piedmont and Montane uplands, than in Provenances 1 and 2, which include the western Gulf Coastal Plain and a portion of the eastern Gulf Coastal Plain. Longleaf pine forests in the Piedmont and Montane uplands of Provenance 4 typically exist on well-drained, rocky, clay soils of exposed ridges and south-facing slopes [29]. However, in some cases, foliar $\delta^{13} \mathrm{C}$ and WUE may vary independently [43]. For example, WUE is related to evaporative demand, which does not directly affect foliar $\delta^{13} \mathrm{C}$, and variation in foliar $\delta^{13} \mathrm{C}$ may be more related to variation in mesophyll conductance than WUE [27]. We suggest that provenance variation in foliar $\delta^{13} \mathrm{C}$ may be related to WUE in this study, because all families at a given provenance test were exposed to the same evaporative demand and provenance variation in SLW was not similar to the variation in foliar $\delta^{13} \mathrm{C}$. The production of thicker or denser leaves associated with increased SLW may increase resistance to $\mathrm{CO}_{2}$ diffusion to the chloroplast and increase foliar $\delta^{13} \mathrm{C}[44,45]$.

No significant genetic by environment or year by genetic by environment interactions were detected for any traits, indicating that provenance rankings were similar across the two sites, which varied in climate and soils, and across the 2 years, which varied in precipitation. These results suggest that provenance variation in the traits studied here may be stable across the species' range. 
Furthermore, trees from Provenance 4 may demonstrate increased foliar $\delta^{13} \mathrm{C}$, and possibly increased WUE, across a range of sites and precipitation regimes and, thus, may be better adapted to a changing climate. Similarly, no genetic by environment interactions for foliar $\delta^{13} \mathrm{C}$ were reported for Picea glauca (Moench) Voss [46], Pinus ponderosa [15], Picea mariana (Mill.) B.S.P. [16], and Pinus radiata [47]. Higher foliar $\delta^{13} \mathrm{C}$ suggests potential genetic adaptation to drought in longleaf pine, but more testing with additional families and direct measurements of WUE under drought stress are needed to confirm not only greater WUE but also greater drought tolerance in this provenance. Although increased WUE can prolong survival under drought [48], it may not in all environments if soil water depletion is not slowed or if plants with high WUE grow faster and use more water [17].

In this study, the provenance with the highest foliar $\delta^{13} \mathrm{C}$ did not demonstrate the greatest or least height. Similarly, at age 6, taller seedlings did not exhibit increased foliar $\delta^{13} C$, perhaps because of genetic variability in the timing of emergence from the grass stage, which can vary by several years [49]. It has been demonstrated that less discrimination by Rubisco against ${ }^{13} \mathrm{C}$ may result in greater productivity, particularly on water-limited sites, and thus, foliar $\delta^{13} \mathrm{C}$ may be a useful selection trait for high WUE without compromising yield [46]. For example, positive genetic correlations between foliar $\delta^{13} \mathrm{C}$ and growth in Pinus radiata indicated that variation in foliar $\delta^{13} \mathrm{C}$ among populations was controlled mainly by variation in photosynthetic capacity [50]. Similarly, in Pinus elliottii (Engelm.) var. elliottii and Pinus caribaea var. hondurensis (Barr. Et Golf.) hybrids, faster growing trees had higher foliar $\delta^{13} \mathrm{C}$ [51]. Since height and foliar $\delta^{13} \mathrm{C}$ were not correlated, it may be possible to select for improved foliar $\delta^{13} \mathrm{C}$ without sacrificing growth in longleaf pine. Conversely, Kerr et al. [52] found reduced growth associated with increased foliar $\delta^{13} \mathrm{C}$ in Pinus ponderosa provenances from drier regions. They concluded that decreased growth was a trade-off for increased drought resistance.

Increased foliar $\delta^{13} \mathrm{C}$ may be a result of increases in photosynthetic capacity [16] or reductions in stomatal conductance related to hydraulic characteristics [53]. Variation in foliar $\delta^{13} \mathrm{C}$ among longleaf pine provenances was not accompanied by provenance variation in foliar $\mathrm{N}$ concentration, suggesting that provenance variation in foliar $\delta^{13} \mathrm{C}$ was a result of differences in stomatal conductance among provenances. A review of genetic variation in the drought tolerance of conifers concluded that in the majority of studies, higher WUE usually resulted from reductions in stomatal conductance, which can limit photosynthesis and growth [17]. Nonetheless, population variation in WUE and stomatal control of water loss have been shown to be related to drought tolerance in pines in some cases [52].

\section{Conclusions}

Despite the limited number of families studied per provenance, range-wide patterns in foliar $\delta^{13} \mathrm{C}$ were found, with greater foliar $\delta^{13} \mathrm{C}$ observed in trees from the provenance consisting of the Piedmont and Montane Uplands than in trees from the provenances representing the western Gulf Coastal Plain and a portion of the eastern Gulf Coastal Plain. Preliminary analysis of longleaf pine provenance tests in Virginia with different families also indicated provenance variation in foliar $\delta^{13} C$ [54], thus supporting our hypothesis that genetic variation in foliar $\delta^{13} \mathrm{C}$ exists in longleaf pine. These results represent the first step in identifying potential genetic variation in WUE and perhaps drought tolerance of longleaf pine. As increased foliar $\delta^{13} \mathrm{C}$ may not be equivalent to increased WUE, and high WUE may not reflect improved drought adaptation $[17,19]$, further testing including more detailed physiological studies are needed to determine if foliar $\delta^{13} \mathrm{C}$ is a useful selection trait in longleaf pine.

Author Contributions: Conceptualization, L.S., K.J. and C.D.N.; Methodology, L.S., K.J., C.D.N., T.S. and P.A.; Formal Analysis, L.S. and T.S.; Writing-Original Draft Preparation, L.S.; Writing-Review \& Editing, L.S., K.J., C.D.N., T.S. and P.A.

Funding: This research was funded by a cooperative agreement between Auburn University and the U.S.D.A. Forest Service, Agreement Number 14-CA-11330137-089. 
Acknowledgments: The authors acknowledge the work of Steve McKeand is designing and installing the provenance tests. Thomas Christensen, John Lewis and Michael Ramirez assisted with data collection and Charles Pell and John Jackson assisted in grinding foliage samples.

Conflicts of Interest: The authors declare no conflict of interest.

\section{References}

1. Schmidtling, R.C. Southern Pine Seed Sources; USDA Forest Service, Southern Research Station: Asheville, NC, USA, 2001; 26p.

2. Noss, R.F.; LaRoe, E.T.; Scott, J.M. Endangered Ecosystems of the United States: A Preliminary Assessment of Loss and Degradation; USDI National Biological Services: Washington, DC, USA, 1995.

3. Diop, A.; Palola, E.; Staudt, A.; Stein, B. Standing tall: How Restoring Longleaf Pine Can Help Prepare the Southeast for Global Warming; National Wildlife Federation: Reston, VA, USA, 2009.

4. Johnsen, K.H.; Butnor, J.R.; Kush, J.S.; Schmidtling, R.C.; Nelson, C.D. Longleaf pine displays less wind damage than loblolly pine. South. J. App. For. 2009, 33, 178-181.

5. Ledig, F.T.; Kitzmiller, J.H. Genetic strategies for reforestation in the face of global climate change. For. Ecol. Manag. 1992, 50, 153-169. [CrossRef]

6. Dorman, K.W. The Genetics and Breeding of Southern Pines; USDA Forest Service: Washington, DC, USA, 1976; 407p.

7. Schmidtling, R.C.; Sluder, E.R. Seed transfer and genecology of longleaf pine. In Proceedings of the 23rd Southern Tree Improvement Conference, Asheville, NC, USA, 20-22 June 1995; Southern Forest Tree Improvement Committee, Ed.; National Technical Information Service: Springfield, VA, USA, 1995.

8. Wells, O.; Wakeley, P.C. Variation in longleaf pine from several geographic sources. For. Sci. 1970, 16, $28-42$.

9. Boshier, D.; Broadhurts, L.; Cornelius, J.; Gallo, L.; Koskela, J.; Loo, J.; Petrokosfsky, G.; St Clair, B. Is local best? Examining the evidence for local adaptation in trees and its scale. Environ. Evid. 2015, 4, 20. [CrossRef]

10. Farquhar, G.D.; O'Leary, M.H.; Berry, J.A. On the relationship between carbon isotope discrimination and the intercellular carbon dioxide concentration in leaves. Aust. J. Plant Physiol. 1982, 9, 121-137. [CrossRef]

11. Ehleringer, J.R. ${ }^{13} \mathrm{C} /{ }^{12} \mathrm{C}$ Fractionation and its utility in terrestrial plant studies. In Carbon Isotope Techniques; Coleman, D.C., Fry, B., Eds.; Academic Press, Inc.: San Diego, CA, USA, 1991; pp. 187-200, ISBN 0-12-179731-7.

12. Correia, I.; Almeida, M.H.; Aguiar, A.; Alia, R.; Davis, T.S.; Pereira, J.S. Variations in growth, survival and carbon isotope discrimination $\left(\delta^{13} \mathrm{C}\right)$ among Pinus pinaster populations of different geographic origins. Tree Physiol. 2008, 28, 1545-1552. [CrossRef] [PubMed]

13. Zhang, J.; Marshall, J.D.; Jaquish, B.C. Genetic differentiation in carbon isotope discrimination and gas exchange in Pseudotsuga menziesii. Oecologia 1993, 93, 80-87. [CrossRef] [PubMed]

14. Xue, J.M.; Clinton, P.W.; Davis, M.R.; Siddiqui, T.; Beets, P.N.; Leckie, A.C. Genotypic variation in foliar nutrient concentrations, $\delta^{13} \mathrm{C}$ and chlorophyll fluorescence in relation to tree growth of radiata pine clones in a serpentine soil. J. Plant Nutr. Soil Sci. 2013, 176, 724-733. [CrossRef]

15. Olivas-Garcia, J.M.; Cregg, B.M.; Hennessey, T.C. Genotypic variation in carbon isotope discrimination and gas exchange of ponderosa pine seedlings under two levels of water stress. Can. J. For. Res. 2000, 30, 1581-1590. [CrossRef]

16. Johnsen, K.H.; Flanagan, L.B.; Huber, D.A.; Major, J.E. Genetic variation in growth and carbon isotope discrimination in Picea mariana: Analyses from a half-diallel mating design using field grown trees. Can. J. For. Res. 1999, 29, 1727-1735. [CrossRef]

17. Moran, E.; Lauder, J.; Musser, C.; Stathos, A.; Shu, M. The genetics of drought tolerance in conifers. New Phytol. 2017, 216, 1034-1048. [CrossRef] [PubMed]

18. Gonzalez-Benecke, C.A.; Martin, T.A. Water availability and genetic effects on water relations of loblolly pine (Pinus taeda) stands. Tree Physiol. 2010, 30, 376-392. [CrossRef] [PubMed]

19. Baltunis, B.; Martin, T.A.; Huber, D.A.; Davis, J.M. Inheritance of foliar stable carbon isotope discrimination and third-year height in Pinus taeda clones on contrasting sites in Florida and Georgia. Tree Genet. Genome 2008, 4, 797-807. [CrossRef]

20. Aitken, S.N.; Yeaman, J.A.; Holliday, T.; Wang, T.; Curtis-McLane, S. Adaptation, migration or extirpation: Climate change outcomes for tree populations. Evol. Appl. 2008, 1, 95-111. [CrossRef] [PubMed] 
21. Schmidtling, R.C. Use of provenance tests to predict response to climatic change: Loblolly pine and Norway spruce. Tree Physiol. 1994, 14, 805-817. [CrossRef] [PubMed]

22. Thomson, A.M.; Parker, W.H. Boreal forest provenance tests used to predict optimal growth and response to climate change. 1. Jack pine. Can. J. For. Res. 2008, 38, 157-170. [CrossRef]

23. Farjat, A.; Reich, B.J.; Guinness, J.; Whetten, R.; Mckeand, S.; Isik, F. Optimal seed deployment under climate change using spatial models: application to loblolly pine in the southeastern US. J. Am. Stat. Assoc. 2017, 112, 909-920. [CrossRef]

24. Craul, P.J.; Kush, J.S.; Boyer, W.D. Longleaf Pine Site Zones; USDA Forest Service, Southern Research Station: Ashville, NC, USA, 2005; 23p.

25. Aspinwall, M.J.; King, J.S.; Domec, J.-C.; McKeand, S.E.; Isik, F. Genetic effects on transpiration, canopy conductance, stomatal sensitivity to vapour pressure deficit, and cavitation resistance in loblolly pine. Ecohydrology 2011, 4, 168-182. [CrossRef]

26. Zhang, J.; Bregg, B.M. Growth and physiological responses to varies environments among populations of Pinus ponderosa. For. Ecol. Manag. 2005, 219, 1-12. [CrossRef]

27. Siebt, U.; Rajabi, A.; Griffiths, H.; Berry, J.A. Carbon isotopes and water use efficiency: Sense and sensitivity. Oecologia 2008, 155, 441-454. [CrossRef] [PubMed]

28. Nelson, C.D.; Boyd, G.; Rousseau, R.J.; Crane, B.S.; Echt, G.S.; Johnsen, K.H. Participatory genetic improvement: Longleaf pine. In Proceedings of the 17th Biennial Southern Silvicultural Research Conference, Shreveport, LA, USA, 5-7 March 2015; Gordon, H.A., Connor, K.F., Haywood, J.D., Eds.; USDA Forest Service, Southern Research Station: Ashville, NC, USA, 2015.

29. Peet, R.K. Ecological classification of longleaf pine woodlands. In The longleaf Pine Ecosystem: Ecology Silviculture, and Restoration; Jose, S., Jokela, E.J., Miller, D.L., Eds.; Springer: New York, NY, USA, 2006; pp. 51-93, ISBN 978-0-387-29655-5.

30. National Centers for Environmental Information: National Oceanic and Atmospheric Administration. Available online: https:/ / www.ncdc.noaa.gov/data-access/land-based-station-data (accessed on 7 May 2018).

31. National Centers for Environmental Information: National Oceanic and Atmospheric Administration. Available online: https:/ /www.ncdc.noaa.gov/cdo-web/datasets/GHCND/stations/GHCND:USC00227840/ detail (accessed on 7 May 2018).

32. National Centers for Environmental Information: National Oceanic and Atmospheric Administration. Available online: https://www1.ncdc.noaa.gov/pub/orders/CDODiv2809097640256.txt (accessed on 7 May 2018).

33. National Centers for Environmental Information: National Oceanic and Atmospheric Administration. Available online: https:/ / www.ncdc.noaa.gov/cdo-web/datasets/GHCND/stations/GHCND:USC00314860/ detail (accessed on 7 May 2018).

34. National Centers for Environmental Information: National Oceanic and Atmospheric Administration. Available online: https://www1.ncdc.noaa.gov/pub/orders/CDODiv8050857640243.txt (accessed on 7 May 2018).

35. Samuelson, L.J.; Seiler, J.R.; Feret, P.P. Gas exchange and canopy structure of 9-year-old loblolly pine, pitch pine, and pitch x loblolly hybrids. Trees 1992, 6, 28-31. [CrossRef]

36. Grulke, N.E. Plasticity in physiological traits in conifers: Implications for response to climate change in the western U.S. Environ. Pollut. 2010, 158, 2032-2042. [CrossRef] [PubMed]

37. Niinemets, U.; Ellsworth, D.S.; Lukjanovan, A.; Tobias, M. Dependence of needle architecture and chemical composition on canopy light availability in three North American Pinus species with contrasting needle length. Tree Physiol. 2002, 22, 747-761. [CrossRef] [PubMed]

38. Eimil-Fraga, C.; Sánchez-Rodríguez, F.; Álvarez-Rodríguez, E.; Rodríguez-Soalleiro, R. Relationships between needle traits, needle age and site and stand parameters in Pinus pinaster. Trees 2015, 29, 1103-1113. [CrossRef]

39. Raison, R.J.; Myers, B.J.; Benson, M.L. Dynamics of Pinus radiata foliage in relation to water and nitrogen stress: I. Needle production and properties. For. Ecol. Manag. 1992, 52, 139-158. [CrossRef]

40. Wright, G.C.; Rao, R.C.N.; Farquhar, G.D. Water use efficiency and carbon isotope discrimination in peanut under water deficit conditions. Crop Sci. 1994, 34, 92-97. [CrossRef]

41. Schmidtling, R.C.; Hipkins, V. Genetic diversity in longleaf pine (Pinus palustris): Influence of historical and prehistoric events. Can. J. For. Res. 1998, 28, 1135-1145. [CrossRef] 
42. Cregg, B.M. Carbon allocation, gas exchange, and needle morphology of Pinus ponderosa genotypes known to differ in growth and survival under drought. Tree Physiol. 1994, 14, 883-889. [CrossRef] [PubMed]

43. Warren, C.R.; Adams, M.A. Internal conductance does not scale with photosynthetic capacity: Implications for carbon isotope discrimination and the economics of water and nitrogen use in photosynthesis. Plant Cell Environ. 2006, 29, 192-201. [CrossRef] [PubMed]

44. Milla-Morena, E.A.; McKown, A.D.; Guy, R.D.; Soollanayakanahally, R.Y. Leaf mass per area predicts palisade structural properties linked to mesophyll conductance in balsam poplar (Populus balsamifera L.). Botany 2016, 94, 225-239. [CrossRef]

45. Vitousek, P.M.; Field, C.B.; Matson, P.M. Variation in foliar $\delta^{13} \mathrm{C}$ in Hawaiian Metrosidieros polymorpha: A case of internal resistance? Oecologia 1990, 84, 362-370. [CrossRef] [PubMed]

46. Sun, Z.L.; Livingston, N.J.; Guy, R.D.; Ethier, G.J. Stable carbon isotopes as indicators of increased water use efficiency and productivity in white spruce (Picea glauca (Moench) Voss) seedlings. Plant Cell Environ. 1996, 19, 887-894. [CrossRef]

47. Korol, R.L.; Kirschbaum, M.U.F.; Farquhar, G.D.; Jeffreys, M. Effects of water status and soil fertility on the C-isotope signature in Pinus radiata. Tree Physiol. 1999, 19, 551-562. [CrossRef] [PubMed]

48. Cregg, B.M.; Zhang, J.W. Physiology and morphology of Pinus sylvestris seedlings from diverse sources under cyclic drought stress. For. Ecol. Manag. 2001, 154, 131-139. [CrossRef]

49. Nelson, C.D.; Weng, C.; Kubisiak, T.L.; Stine, M.; Brown, C.L. On the number of genes controlling the grass stage in longleaf pine. J. Heredity 2003, 94, 392-398. [CrossRef]

50. Xue, J.; Dungey, H.S.; Clinton, P.W.; Henley, D.; Niollet, S.; Leckie, A. The Potential for Using Foliar Carbon Isotopic Signature to Screen for Drought Tolerant Radiata Pine Genotypes for Dryland Plantation Forests in New Zealand; MPI Technical Paper No. 2013/38; Ministry for Primary Industries: Wellington, New Zealand, 2013.

51. Prasolova, N.V.; Xu, Z.H.; Lundvist, K.; Faruhar, G.D.; Dieters, M.J.; Walker, S.; Saffigna, P.G. Genetic variation in foliar carbon isotope composition in relation to tree growth and foliar nitrogen concentration in clones of the F1 hybrid between slash pine and Caribbean pine. For. Ecol. Manag. 2003, 172, 145-160. [CrossRef]

52. Kerr, K.L.; Meizer, F.C.; McCulloch, K.A.; Woodruff, D.R.; Marias, D.E. Expression of functional traits during seedling establishment in two populations of Pinus ponderosa from contrasting climates. Tree Physiol. 2015, 35, 535-548. [CrossRef] [PubMed]

53. Samuelson, L.J.; Kane, M.; Markewitz, D.; Teskey, R.; Akers, M.; Stokes, T.; Pell, C.; Qi, J. Fertilization increased leaf water use efficiency and growth of Pinus taeda subjected to five years of throughfall reduction. Can. J. For. Res. 2018, 48, 236-245. [CrossRef]

54. Johnsen, K.H.; Creighton, J.L.; Maier, C.A. Longleaf pine grown in Virginia: A provenance test. In Proceedings of the 17th Biennial Southern Silvicultural Research Conference, Shreveport, LA, USA, 5-7 March 2015; Gordon, H.A., Connor, K.F., Haywood, J.D., Eds.; USDA Forest Service, Southern Research Station: Ashville, NC, USA, 2015.

(C) 2018 by the authors. Licensee MDPI, Basel, Switzerland. This article is an open access article distributed under the terms and conditions of the Creative Commons Attribution (CC BY) license (http:/ / creativecommons.org/licenses/by/4.0/). 